\title{
Occurrence and Distribution of Banana bunchy top virus Related Agro-Ecosystem in South Western, Democratic Republic of Congo
}

\author{
Lyna Fama Tongo Mukwa ${ }^{1,2}$, M. Muengula3 ${ }^{3}$, I. Zinga4, A. Kalonji3, M. L. Iskra-Caruana5, \\ C. Bragard ${ }^{2}$ \\ ${ }^{1}$ Clinique des Plantes de Kinshasa, Kinshasa, Democratic Republic of the Congo \\ ${ }^{2}$ Earth and Life Institute, Applied Microbiology-Phytopathology, Université Catholique de Louvain, Louvain-la- \\ Neuve, Belgium \\ ${ }^{3}$ Faculté des Sciences Agronomiques de l'Université de Kinshasa, Kinshasa, Democratic Republic of the Congo \\ ${ }^{4}$ Laboratoire des Sciences Biologiques et Agronomiques pour le Développement (LASBAD), Université de \\ Bangui, Bangui, Central African Republic \\ ${ }^{5}$ Centre International de Recherche Agronomique pour le Développement, Montpellier, France \\ Email: "lynamukwa@yahoo.fr
}

Received 16 December 2013; revised 12 February 2014; accepted 1 March 2014

Copyright (C) 2014 by authors and Scientific Research Publishing Inc.

This work is licensed under the Creative Commons Attribution International License (CC BY).

http://creativecommons.org/licenses/by/4.0/

(c) (i) Open Access

\section{Abstract}

Banana bunchy top virus (BBTV) is one of the most severe and widespread virus limiting production and distribution of planting material of banana (Musa spp.) crops in the world. In Democratic Republic of Congo (DRC), these crops play a major role in daily life of almost $70 \%$ of citizen. Many factors influence banana production negatively such as Banana bunchy top disease. Epidemiological survey was conducted in experimental stations and farmers' fields for two consecutive seasons covering 72 sites in five provinces of south western of RDC. The objective of this study was to evaluate the presence and distribution of the Banana bunchy top virus in five provinces of South Western of DRC, with emphasis on the agro-ecological factors. A total of 174 Musa spp. leaves samples were collected and analyzed by PCR. The results revealed the presence of BBTV in all provinces investigated. The frequency of BBTV was $6.3 \%$ in Bandundu, 12.1\% in Kasaï Oriental, $\mathbf{1 7 . 8 \%}$ Bas Congo, $\mathbf{1 . 1 \%}$ in Katanga and $\mathbf{7 . 5 \%}$ Kinshasa Urban and Peri-urban. Results also revealed that BBTV occurred in experimental station and farmers' fields, both having all cooking and dessert bananas. The high prevalence of BBTV seemed to be linked to multiple introductions of planting materials in the Bas Congo province during 1990 and 2002. However, the province of Ka-

\footnotetext{
${ }^{*}$ Corresponding author.
}

How to cite this paper: Mukwa, L.F.T., et al. (2014) Occurrence and Distribution of Banana bunchy top virus Related Agro-Ecosystem in South Western, Democratic Republic of Congo. American Journal of Plant Sciences, 5, 647-658. 
tanga had not experienced the introduction of planting material. This factor would explain the lowest prevalence of Banana bunchy top virus in this province. The results indicated that there was a real need to facilitate access to genetically improved and healthy certified planting material in these provinces.

\section{Keywords}

\section{Banana; Banana bunchy top virus (BBTV); Farmers' Fields; Agro-Ecological Conditions; Democratic Republic of Congo}

\section{Introduction}

Banana and plantains (Musa sp.) are one of the most major crops in Democratic Republic of Congo. Plantain is considered as the second most important staple food after cassava (Manihot esculenta) [1]-[3]. More or less 70\% of the Congolese population consumes daily banana in various forms such as either in crushed mixte with cassava, chips or in manufacture of traditional wine [4]. Banana and plantain is grown throughout the country in all agro ecological conditions. That basin of Congo is considered as a secondary centre of diversity of plantain [5].

Ten years ago, banana production and area planted have been reported to decline between $20 \%$ and $60 \%$ [5]. Production of banana and plantain appears to be negatively influenced by agro-ecological factors. It is affected by many pests and diseases including nematodes, weevils, Black leaf streak disease, Xanthomonas wilt disease and Banana bunchy top disease (BBTD).

In most cases, the loss of $90 \%-95 \%$ was observed in Cavendish variety [6]. Banana bunchy top disease (BBTD) alone can cause yield losses up to 100\% [7]. Therefore, it is recognized as the most devastating viral disease of banana in the word, particularly in DRC. Also, it is one of the major constraints in the distribution of planting material [5] [8]-[11].

Banana bunchy top disease (BBTD) caused by Banana bunchy top virus (BBTV), a virus of Nanoviridae family, genus: Babuvirus. Viral capsid has multi-component single-stranded DNA genomes encapsidated in small isometric particles $(18-20 \mathrm{~nm})$ [8] [12]. BBTV is transmitted plant-to-plant by the aphid vector Pentalonia nigronervosa [13]-[16]. Dwarfing, narrow leaf, chlorosis of leaf margins and discontinuous dark-green streaks on leaves, petioles and pseudotem characterize the disease. The leaves of infected plants become progressively smaller and stand more erect giving the plant a bunchy appearance [17]. Plants infected early in their grown do not produce fruit resulting in total loss of yield, while plant infected at later stages may produce normal or deformed fruits.

In Democratic Republic of Congo, BBTD has been observed for the first time, around 1958, in the Kisangani region [6] [18]. From there, the disease quickly spreads to other regions. Little is known, however, on the distribution of the disease, the agro-ecological factors favoring or limiting the distribution of the virus in DRC. The aim of this study therefore was to investigate the distribution of BBTV in five provinces of South Western of DRC, with indications on the agro-ecological factors contributing to the presence and spread of the Banana bunchy top disease.

\section{Materials and Methods}

\subsection{Epidemiological Survey}

Five South Western province of the country, where prevailing different pedo-climatic conditions, were used for this study. The province of Katanga and Kasaï-Oriental; with a tropical climate type Aw6 according to Köppen climate classification-Were average daily temperature varies between $19^{\circ} \mathrm{C}$ and $20^{\circ} \mathrm{C}$, the average annual rainfall is $1.226 \mathrm{~mm}$. The floor of Katanga, in places, three different geological types. The soils of Kasaï Oriental province belong to the order of Kaolisols [19]. Bandundu, Bas-Congo and Kinshasa urban and peri-urban, most of which is located in the natural setting of the central basin, have two types of climatic zones: the tropical climate on the one hand and the other part equatorial climate. The daily temperature is $25^{\circ} \mathrm{C}$ with very little variation; average annual rainfall amounts to $1500 \mathrm{~mm}$. the soil of three provinces are extremely diverse. 
Epidemiological surveys were conducted in farmer's fields over a 2 years period in Bas-Congo and Kinshasa urban and peri-urban areas, in Katanga, Kasaï-Oriental and Bandundu. A total of 72 sites were surveyed (Figure 1) 6 sites in Katanga, 16 sites in Kasaï-Oriental, 11 sites in Kinshasa urban and peri - urban areas, 16 sites in Bas Congo and 23 sites in Bandundu. In each site three farmers' fields were randomly selected (Table 1).

Using a questionnaire designed for this purpose, the producer responsible for the field was individually interviewed.

A result of the interviews with the producer, the banana leaf samples with typical symptoms and asymptomatic were collected. Banana leaf samples were stored in tubes as Bas samples, containing over anhydrous calcium chloride (Cacl2).

\subsection{Detection of Banana bunchy top virus by PCR}

The total DNA was extracted from $100 \mathrm{mg}$ of leaf samples by the method described by Dellaporta [20]. Banana bunchy top virus detection was performed by polymerase chain reaction using the primer pair BBTV1f/BBTV1r (GCGTGAAACGCACAAAAGGCC and GCATACGTTGTCAAACCTTCTCCTC) designed to amplify a 240 bp product corresponding to the care region of DNA-R. An initial cycle of denaturation at $95^{\circ} \mathrm{C}$ for 10 minutes followed by 34 cycles of $\left(95^{\circ} \mathrm{C}\right.$ for $30 \mathrm{sec}, 55^{\circ} \mathrm{C}$ for $45 \mathrm{sec}, 72^{\circ} \mathrm{C}$ for $\left.30 \mathrm{sec}\right)$ and the finally extension at $72^{\circ} \mathrm{C}$ for 10 minutes [10].

The frequency or incidence of Banana bunchy top virus in each province was calculated by establishing the ration between the total number of positive samples and the total number of samples tested, multiplied by 100 .

\subsection{Agro-Ecologicals Factors}

For each field surveys, agro-ecological characteristics were taken into account. These include the production system in which the banana growing, genotype, cultivar type, source of planting material, monitoring the health status before planting, the type of fertilization, the number of fertilization banana during the complete cycle of the plant, the type of maintenance, treatment plant, intercropping system, altitude and crop age.

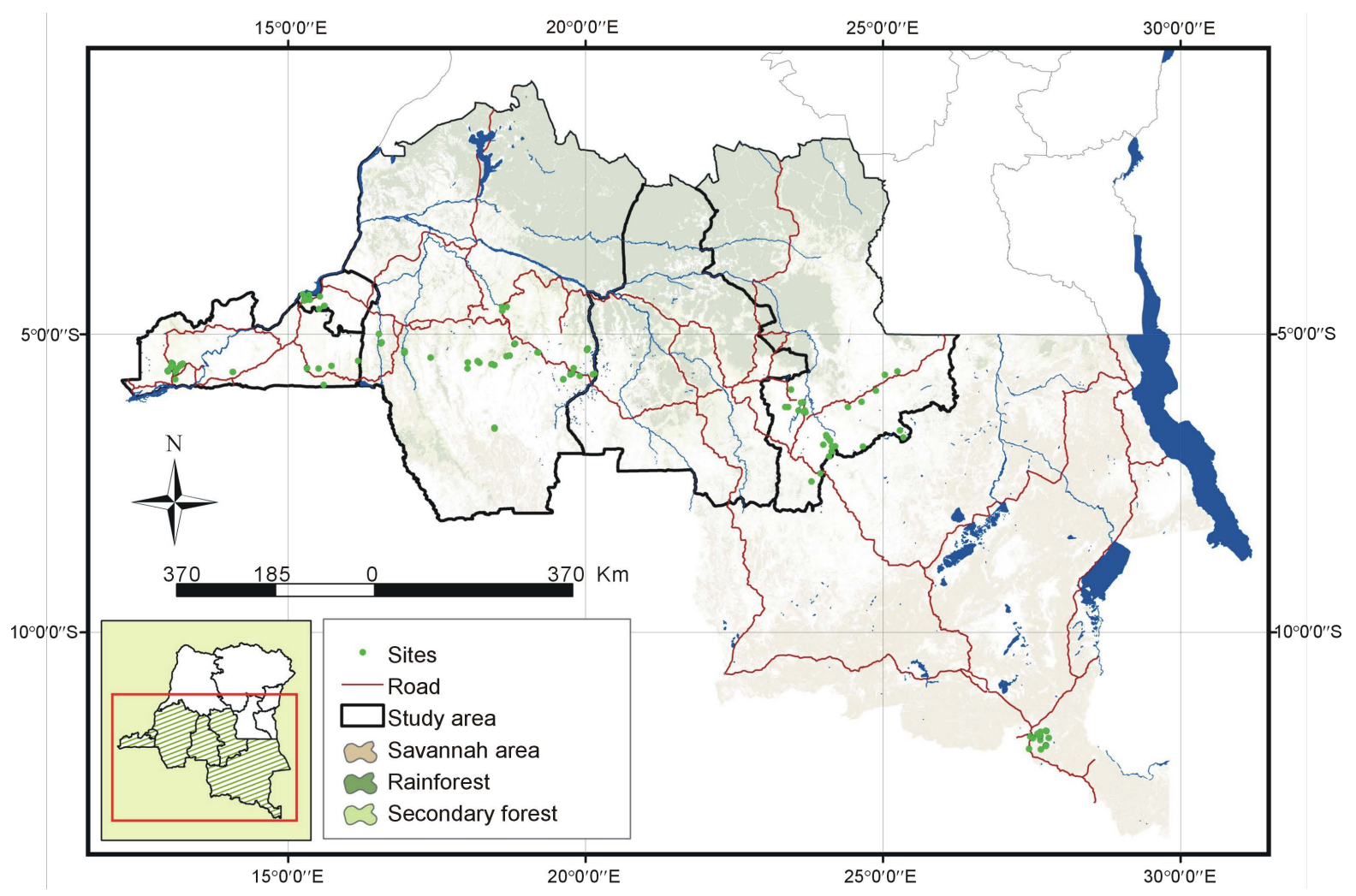

Figure 1. Map of the five provinces of Democratic republic of Congo showing locations of site surveyed. 
Table 1. Agro-ecological characteristics of the farmer's fields in five provinces surveyed.

\begin{tabular}{|c|c|c|c|c|c|}
\hline \multirow[b]{2}{*}{ Observed parameters } & \multicolumn{5}{|c|}{ South western Provinces surveyed } \\
\hline & (\%) Bandundu & (\%) Katanga & (\%) Kassaï Oriental & $\begin{array}{l}\text { (\%) Kinshasa Urb } \\
\text { \& Peri Urbban }\end{array}$ & $\begin{array}{l}\text { (\%) Bas } \\
\text { Congo }\end{array}$ \\
\hline \multicolumn{6}{|l|}{ 1. Cropping System } \\
\hline Planting around dwellings & 89.7 & 60.0 & 100 & 100 & 70.0 \\
\hline Forest plantation & 5.2 & 0 & 0 & 0 & 15.0 \\
\hline Experimental plantation & 5.2 & 40.0 & 0 & 0 & 15.0 \\
\hline \multicolumn{6}{|l|}{ 2. Genotype } \\
\hline Plantain & 32.8 & 16.7 & 71.9 & 42.9 & 62.5 \\
\hline Dessert banana & 67.2 & 83.3 & 28.1 & 57.1 & 37.5 \\
\hline Banana beer & 0 & 0 & 0 & 0 & 0 \\
\hline \multicolumn{6}{|l|}{ 3. Type of variety (Planting material) } \\
\hline Locale varieties & 72.4 & 76.7 & 87.5 & 100 & 100 \\
\hline Improved varieties & 27.6 & 23.3 & 12.5 & 0 & 0 \\
\hline \multicolumn{6}{|l|}{ 4. Health status of planting material } \\
\hline Known ( controlled and certified laboratoyr) & 0 & 0 & 0 & 0 & 0 \\
\hline Unknown ( not certified, not checked) & 100 & 100 & 100 & 100 & 100 \\
\hline \multicolumn{6}{|l|}{ 5. Origin of planting material } \\
\hline Research center & 5.2 & 0 & 0 & 0 & 15.0 \\
\hline ONGDs or farmer's association & 0 & 0 & 0 & 0 & 0 \\
\hline Previous crop & 94.8 & 100 & 100 & 100 & 85.0 \\
\hline \multicolumn{6}{|l|}{ 6. Age of field } \\
\hline 1 to 6 months & 6.9 & 0 & 12.5 & 0 & 5.0 \\
\hline 7 to 12 months & 13.8 & 55.5 & 31.2 & 21.4 & 35.0 \\
\hline More than 12 months & 79.3 & 44.4 & 56.2 & 46.7 & 60.0 \\
\hline \multicolumn{6}{|l|}{ 7. Type of fertization } \\
\hline Organic & 86.2 & 56.7 & 100 & 78.6 & 77.5 \\
\hline Mineral & 0 & 0 & 0 & 0 & 0 \\
\hline Organic and Mineral & 1.7 & 33.3 & 0 & 0 & 7.5 \\
\hline No fertization & 12.1 & 10.0 & 0 & 21.4 & 15.0 \\
\hline \multicolumn{6}{|l|}{ 8. Fertilizer application number } \\
\hline Once at planting & 72.4 & 33.3 & 87.5 & 28.6 & 57.5 \\
\hline Twice at planting and during the cultural cycle & 1.7 & 0 & 0 & 0 & 0 \\
\hline Several times during the cycle & 12.1 & 50 & 12.5 & 57.1 & 27.5 \\
\hline No fertilizer application & 13.8 & 16.7 & 0 & 14.3 & 15.0 \\
\hline \multicolumn{6}{|l|}{ 9. Traitement phytosanitairy } \\
\hline No phytosanitary treatment & 100 & 96.6 & 100 & 100 & 100 \\
\hline Phytosanitary treatment & 0 & 3.4 & 0 & 0 & 0 \\
\hline \multicolumn{6}{|l|}{ 10. Crops Association } \\
\hline Yes & 67.2 & 30.0 & 59.4 & 64.3 & 80.0 \\
\hline Not & 32.8 & 70.0 & 40.6 & 35.7 & 20.0 \\
\hline \multicolumn{6}{|l|}{ 11. Topography of the land } \\
\hline Sloping & 15.5 & 0 & 0 & 7.1 & 5.0 \\
\hline Flat land & 37.9 & 66.7 & 56.2 & 21.4 & 30.0 \\
\hline Top of Hill & 22.4 & 10.0 & 0 & 21.4 & 32.5 \\
\hline Valley & 24.1 & 23.3 & 43.8 & 50.0 & 32.5 \\
\hline \multicolumn{6}{|l|}{$\begin{array}{l}\text { 12. Other type of maintenance ( Weeding, } \\
\text { hilling, desuckering, coppicing, staking) }\end{array}$} \\
\hline Yes & 25.9 & 0 & 0 & 21.4 & 12.5 \\
\hline Not & 74.1 & 100 & 100 & 78.6 & 87.5 \\
\hline \multicolumn{6}{|l|}{ 13. Distribution of BBTV } \\
\hline Prevalence of infecting plantation & 6.3 & 1.1 & 12.1 & 7.5 & 17.8 \\
\hline
\end{tabular}




\subsection{Data Analysis}

At the end of the investigations on the agro- ecological factors, the survey questionnaires were stripped and proportion of each parameter were calculated by comparing the number of observed parameter on the total number of fields investigated in the province. The logiciel $\mathrm{R}$ was used to analyze parameters, the standard deviation was calculated, the variance and the correlation between different parameters were established.

This analysis has allowed to evaluate each parameter and highlights the major constraints that effect banana cultivation in DRC.

\section{Results}

\subsection{Detection of Banana bunchy top virus}

A total of 174 symptomatic and asymptomatic samples, collected from five provinces of South Western democratic republic of Congo. The result revealed that 77 samples, or $44.8 \%$ of the plantations surveyed, analyzed were positive to Banana bunchy top virus (Figure 2).

The expected BBTV DNA fragment of 240bp was amplified from leaf tissue samples (Appendix Figure 1 \& 2).

\subsection{Banana Bunchy To Virus Distribution in South Western Democratic Republic of Congo}

In the five provinces concerned by this study, Banana bunchy top virus was present in every type of cropping system (Figures 2 \& 3). In farmer's field, plantation, experimental station, both in forest and savannah area (Figure 2). BBTV also detected in all type of banana (Cooking and dessert).

Results indicate that the level of prevalence of BBTV is variable in each province. Five provinces studied, the highest frequency of BBTV was observed in the Bas-Congo province $(17.8 \%)\left(\mathrm{X}^{2}=69.27\right.$; $\left.\mathrm{ddl}=4 ; \mathrm{p}=0\right)$ and lowest frequency was observed in the Katanga province (1.1\%). In between Kasai-oriental (12.1\%) and Kinshasa urban and pre-urban (7.5\%) and Bandundu has an infection rate of $6.3 \%$ recorded middle range prevalence (Figure 3).

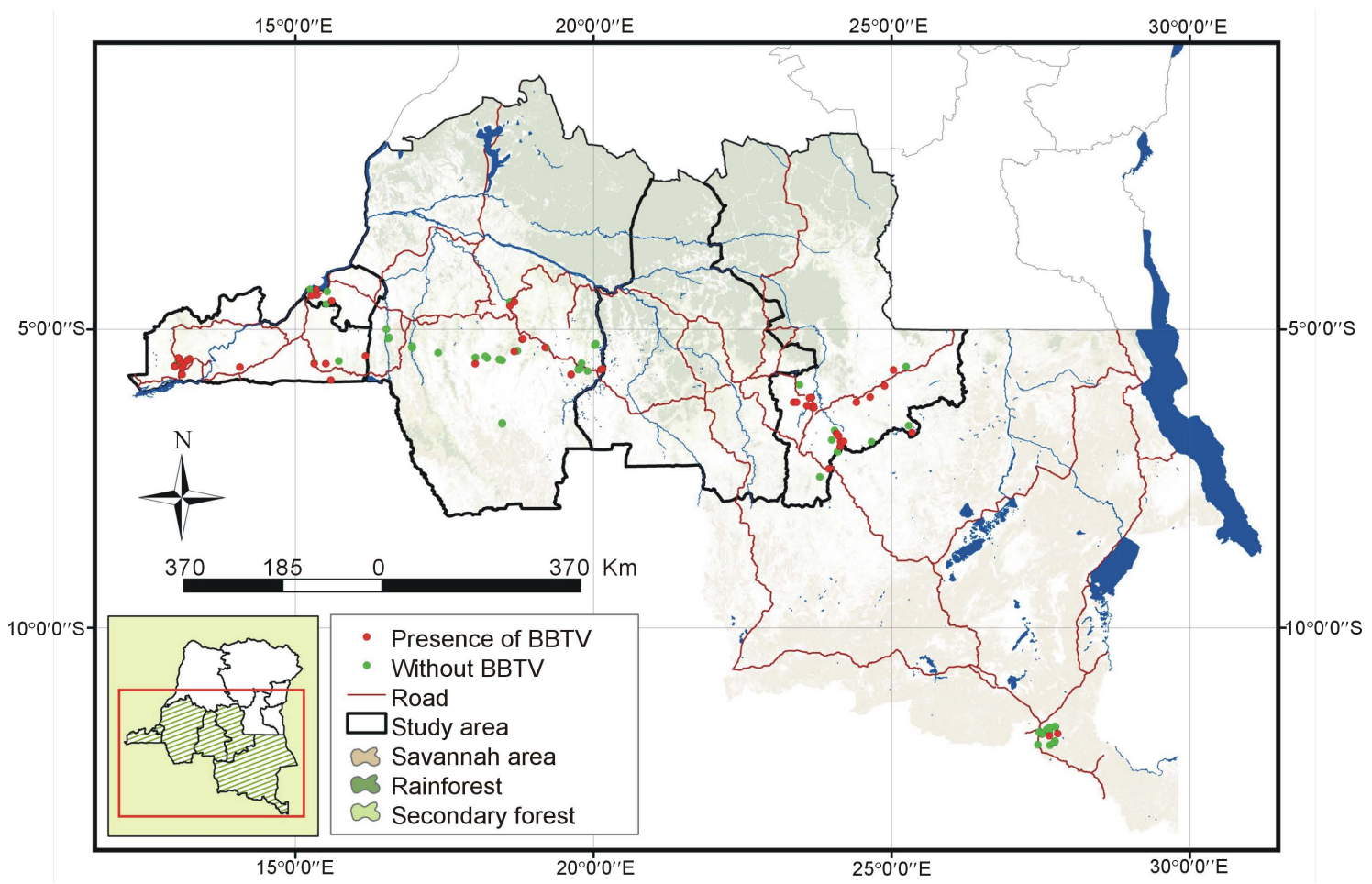

Figure 2. Map showed Banana bunchy top virus distribution in South Western democratic republic of Congo (Red dots show the locations where BBTV was detected). 


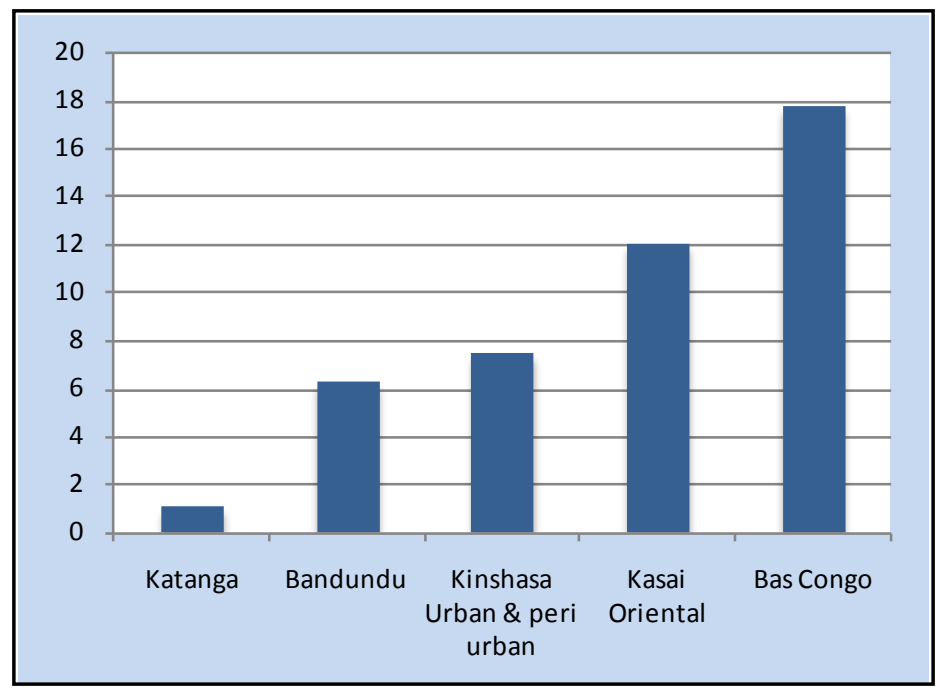

Figure 3. Frequency (\%) of Banana bunchy top virus in five provinces Surveyed.

To understand distribution of BBTV, agro-ecological characteristics of the sites surveyed were also studied; the results are shown in Table 1.

\subsection{Agro Ecologicals Factors Analysis}

\section{- Planting material quality origin and varieties}

Banana and plantain are vegetatively propagated plant. The crop thus requires the use of certified and healthy planting material. Results of this investigation indicate that planting materials used in both experimental station, and in farmer's field are not always healthy and certified.

\section{- Origin and varieties}

Planting materials was of unknown healthy status in $100 \%$ of cases. The varieties used in research station and farmer's field are local varieties, from previous culture and frequently of unknown origin (Table 1). However, local varieties used in research centre originate from their collection. In the five provinces surveyed, the frequency of cooking banana and banana dessert proved variable. Cooking banana is predominant in Kasaï Oriental and Bas Congo (71.9\% and 62.5\%) banana dessert is predominant in Bandundu, Katanga and Kinshasa urban and peri-urban (frequency of 67.2\%; 83.3\%; 57.1\%). Banana grown for beer has not been surveyed in the selected sites.

\section{- Cropping system, fertilization and use of fertilizers in banana cultivation}

The survey of 72 sites in five provinces of the South Western of the country indicate that the banana and plantain are grown mostly in the cropping system of plantations around dwelling, where fertilization is mostly organic with a low frequency of fertilization. Most of the time, the supply of organic fertilizer is done before planting. This observation was performed in all types of cropping system.

In Katanga and Kinshasa urban and peri-urban, in respectively $50 \%$ and $57.1 \%$ of cases, the banana is fertilized at planting and during the cycle. The regular intake of leaves and waste are carried out (Table 1).

The plant remains longer in the same place without renewed strain.

The age of the plantation is usually more than 12 months, and interviews are not made or if they are made they are limited to weeding-ridging (25.9\% Bandundu, Kinshasa urban and peri-urban 21.4\%, Bas Congo, $12.5 \%)$. The banana adapts in a moist environment at high humidity greater than $60 \%$, with deep, loamy, well-drained $\mathrm{pH}$ between 4.0 and 8.0 .

Nitrogen, phosphorus and potassium are major elements essential to the growth of the banana. The $\mathrm{Ca}$ and $\mathrm{Mg}$ are also needed to culture [21]. Aside from soils mountainous regions of the country, the Congolese soils are mostly lateritic, leached, acid and poor. The conclusions of the work of Dowiya [22] have shown that, in Eastern Democratic Republic of Congo, soil fertility was not a constraint for banana cultivation. In South west, the soil is limiting factor that need special attention. Culture of banana made without the input of mineral fertilizer or 
organic in the cycle of the plant, rapidly degrades soil quality and yield reduction was observed consecutively. This partly explains the existence of extensive cultivation among farmers.

Productivity of the banana depends on natural conditions controlled or mastered by the best facilities, cultivation techniques, pesticides treatments etc. [9].

\section{- Use of chemical treatment}

Results of the investigations presented in Table 1 shows that 100\% of farmers do not use chemical pesticides despite the high pest pressure. Only experimental stations in Katanga province use fungicides for control of foliar pests. Management of pests and diseases of banana implies the short-term use of chemical pesticides with significant environmental risks. The lack of chemical pesticides and non-pesticide use inhibit the growth of production and therefore discourages intensification of banana cultivation. This result suggest that a sustainable alternatives and/ or effective would be the development of rational strategies of disease management, the definition of good agricultural practices necessary to reduce pest pressure. The search for varieties resistant to these diseases and the development of biological control methods suitable and more efficient are way to sustainable disease control.

\section{- Care cropping}

Banana cultivation is carried out in bulk without additional crop tending. In the study area, Bandundu, Katanga, Kasaï Oriental, Kinshasa urban and peri-urban, bas Congo, bananas do not receive any cultural care, respectively in $74.1 \%$ of cases, $100 \%, 100 \%, 78.6 \%$ and $87.5 \%$. In the remaining cases, in the province of Bandundu, Kinshasa urban and peri urban, bas Congo, the banana is just weeded, stumbled and staked to prevent the fall of the plant, related to the wind.

\section{Discussion}

Banana bunchy top virus cause economically important disease. It is one of the major constraints for Musa germoplasm movement and vegetative propagation [1] [9] [23]-[27]. A variety of factors including virus isolate, host genotype, level of crop management and agro-ecological conditions influence symptoms expression which is variable and discontinuous [28]. Conventional control such as quarantine, eradication and certified virus free stock have successfully been use to reduce crop losses caused by this virus [9] [29].

To control this disease requires that the current distribution, the agro-ecological characteristics where banana grown and agro-ecological factors promoting the distribution of the disease be determinate in order to develop strategies specific management BBTD.

The work reported here established the level of infection and distribution of Banana bunchy top disease in agro-ecological conditions of five provinces of Democratic Republic of Congo.

The results of this study reveal that Banana bunchy top disease is present in all provinces and is highly distributed.

In total, $44.8 \%$ of banana plantations in the South Western of the country are Banana bunchy top virus infected. This result joins the conclusions of investigations of other authors [10]. Comparing the level of infection of five provinces, result shows that the highest incidence of BBTV was observed in Bas Congo, where 17.8\% of banana plantations are infected. These results seem to be linked to multiple introductions of improved varieties in each territory of this province between 1990 and 2002 [30].

The province of Katanga has not experienced the introduction of improved planting material. This factor would explain the low incidence (1.1\%) of Banana bunchy top virus.

Observation during our investigation confirmed that planting material use in all province of South Western of Democratic Republic of Congo are local varieties, uncertified healthy. The results join the conclusions of the work of other authors [22], which stated that there is not, in East of DRC, the structure of improved varieties of banana, although the sanitary control of planting material is currently provided by the Plant Clinic of Kinshasa. But $100 \%$ of planting materials are uncontrolled banana suckers.

Surveys revealed that the uncontrolled exchange of non-certified and healthy planting materials, the use of local varieties of uncertain origin, contributes significantly to the spread of the disease. Observations made also by team Lava Kumar [10].

Examples of experimental fields in Katanga province, where samples are collected in experimental plantation of the faculty of Agronomy, where banana varieties harvested in different parts of the province have been field to explore their potential agronomic. Although the prevalence of BBTV is low in this province, it appears that in 
the experimental fields 2 samples in 10 are BBTV positives or (20\%). Whether while in the province of bas Congo in research station an average two samples of 3 are positive BBTV.

Banana (Musa spp.) is a culture of high agricultural potential in DRC [31] [32].

Results obtained in this study suggest that, the banana yield decline in south western of DRC is partly be caused by Banana bunchy top virus. It is probably only one of number of factors that are responsible for the decline. Banana is cultivated several year-round in some place. This practice contributes not only to a decrease in land fertility, but to the accumulation of other diseases like BBTV [28]. The techniques of production remains rudimentary, the incidence of Banana bunchy top virus is high and Banana bunchy top disease is very widespread in all provinces studied. This factor influences negatively the performance of banana. Thus, it appears that there is a real need for certified planting material and improved, a need for improving conditions of banana production, technical itineraries incorporating the constraint condition and diagnostic tools [33]. This work is only preabule to the development of management strategies, control of Banana bunchy top disease and the improvement of banana production in the democratic republic of Congo.

\section{Conclusions}

Banana bunchy top virus is established and is spreading across agro-ecological conditions where banana is cultivated, particularly in South Western democratic republic of Congo. BBTV is also presented in experimentation station. In view of the major role to be played by the research institution, the frequency of BBTV observed is very high and worrying.

There is a real need for establishing control strategies at different levels: among farmers and state level:

- Levels of farmers: the learning to recognize the BBTD symptoms, the destruction of infected plants and the use of healthy planting material certified.

- Level of state: control strategies including the creation of buffer zones quarantine, the development of biological control methods against the vector (Pentalonia nigronervosa Coquerel), the development of varieties resistant, sensitive, effective and appropriate to the context of Congolese agriculture, support institutions dedicated to the control of planting material. The implementation of the strategies will support the control of Banana bunchy top virus.

\section{Acknowledgements}

We thank the Direction of Statistics of the National Institute of Agronomic Research of INERA/ DRC, the Belgian development agency which funded this study, the technical staff and all the technicians of the International Plant Clinic and any person who, in one way or another to contribute to this study.

\section{References}

[1] Tushmereirwe, W.K. and Bagabe, M. (1999) Review of Disease Distribution and Pest Status in Africa. In Review of IPM Research Activities-Pathology, 139-147.

[2] Van Damme, J. (2008) Analyse Systémique des Contraintes en Culture Bananiere au Rwanda, Mémoire Inédit. Université catholique de Louvain, Belgique, 107.

[3] Website. www.faostat.org

[4] Institut National de Statistique (2006) Rapport Annuel de la Direction des Statistiques Démographiques et Sociales, Kinshasa, RDC, 203.

[5] Mobambo, P., Staver, C., Hauser, S., Dheda, B. and Vangu, G. (2010) An Innovation Capacity Analysis to Identificatify Strategies for Improving Plantain and Banana (Musa spp.) Productivity and Value Addition in the Democratic Republic of Congo. Acta Horticulturae, 879, 821-828.

[6] Caruana-Iskra, M.L. (2003) Analyse du Risque Phytosanitaire (ARP). Organisme Nuisible, Banana Bunchy Top Babuvirus-BBTV Zones ARP: Martinique, 7-14.

[7] FAO (2009) Travailler Ensembles Lutter contre les Maladies de la Banana en Afrique Subsaharienne. Bulletin d'Information. www.fao.org

[8] Shiragi, H., Baque, A. and Nasiruddin, K. (2010) Eradication of Banana bunchy top virus (BBTV) through Meristem Culture of Infected Plant Banana cv. Sabri. Horticulture Environment and Biotechnology, 51, 212-221.

[9] Lassoudière, A. (2012) Le bananier, un Siècle d’Innovations Technique. Editions Quae, Versailles, 352. 
[10] Lavakumar, P., Hanna, R., Alabi, O.J., Soko, M.M., Oben, T.T., Vangu, G.H.P. and Naidu, R.A. (2011) Banana bunchy top virus in Sub-Saharan Africa: Investigations on Virus Distribution and Diversity. Virus Research, 159, 171-182. http://dx.doi.org/10.1016/j.virusres.2011.04.021

[11] Aritua, V., Nanyonjo, A., Kumakech, F. and Tushemereirwe, W. (2007) Rep-PCR Revels High Homogeneity among Ugandan Issolates of Xanthomonas Campestris pv. Musacearum. African Journal of biotechnology, 6, 179-183.

[12] Mansoor, S., Qazi, J., Amin, I., Khatri, A., Khan, A.I., Raza, S., Zafar, Y.Y. and Bridon, B.W. (2005) A PCR-Based Method, with Internal Control, for the Detection of Banana bunchy top virus in Banana. Molecular Biotechnology, 30, 2005, pp. 167-170. http://dx.doi.org/10.1385/MB:30:2:167

[13] Amine, I., Ilyas, M., Qazi, J., Bashir, R., Yadav, J., Mansoor, S., Fauquat, M.C. and Briddon, W. (2011) Identification of a Major Pathogenicity Determinant and Suppressors of RNA Silencing Encoded by a South Pacific Isolate of Banana Bunchy Top Virus Originating from Pakistan. Virus Gens, 42, 272-281.

[14] Lockhart, B.E.L. (2002) Management of Viral Diseases of Banana. Correspondance Scientifique (Conference Magistral) Department of Plant Pathology, University of Minnesota, 217-221.

[15] Anhalt, M.D. andAlmeida, R.P.P. (2008) Effect to Temperature, vector Life stage, and Plant Access Period on Transmission of Banana bunchy top virus to Banana. American Phytopathological Society, 98, 743-746.

[16] Padmalatha, C. and Sigh, A.J.A.R. (1998) Aphidophagus Coccinellids on Pentalonia nigronervosa, a Vector of Banana bunchy top virus in the Banana Plants of Southwest India. Tropical Ecology, 39, 239-242.

[17] Gatsinzi, F. (1987) Les Principales Maladies et Ravageurs du Bananier au sein de la CEPGL in Séminaire sur les Maladies et Ravageurs des Principales Cultures Vivrières d’Afrique Centrale. Iraz, CTA, Bujumbura.

[18] Buycks, E.J.E. (1962) Précis des Maladies et des Insects Nuisibles Rencontrés sur les Plantes Cultivées au Congo, au Rwanda et au Burundi, I.N.E.A.C.

[19] Kabulu, J.P. (2006) Evaluation et Cartographie de la Deforestation au Katanga (RDC), Mémoire on Line, ULB, Belgique, 84.

[20] Dellaporta, S.L., Wood, J. and Hicks, J.B. (1983) A Plant DNA Mini Preparation: Version II. Plant Molecular Biology Reporter, 4, 19-21. http://dx.doi.org/10.1007/BF02712670

[21] Anonyme (2009) Memento de l'Agronome, CTA, Paris, 1689.

[22] Dowiya, N.B., Rweyemamu, C.P. and Maerere, A.P. (2009) Banana (Musa spp. Colla), Cropping Systems, Production Constraints and Cultivars Preferences in Eastern Democratic Republic of Congo, 341-355.

[23] Sharman, M., Thomas, J.E. and Dietzgen, G.R. (2000) Development of a Multiplex Immunocapture PCR with Colourimetric Detection for Viruses of Banana. Journal of Virological Methods, 89, 75-88. http://dx.doi.org/10.1016/S0166-0934(00)00204-4

[24] Harish, S., Kavino, M., Kumar, N., Saravanakumar, D., Soorianathasundaram, K. and Samiyappan, R. (2008) Biohardening with Plant Growth Promoting Rhizosphere and Endophytic Bacteria Induces Systemic Resistance against Banana Bunchy top Virus. Applied Soil Ecology, 39, 187-200.

[25] Diekmann, M. and Putter, C.A.J. (1996) Musa spp.: Technical Guidelines for the Safe Movement of Germoplasm, No. 15, FAO/IPGRI.

[26] Wardlaw, C.W. (1961) Banana Diseases: Including Plantains and Abaca. Longmans, London.

[27] Teycheney, P.Y., Acina, I., Lockhart, B.E.L. and Candresse, T. (2007) Detection of Banana Mild Mosaic Virus and Banana Virus X by Polyvalent Degerate Oligonucleotides RT-PCR (PDO RT-PCR. Journal of Virological Methods, 142, 41-45.

[28] Harper, G., Hart, D., Moult, S and Hull, R (2004) Banana Streak Virus Is Very Diverse in Uganda. Virus Research, 100, 51-56. http://dx.doi.org/10.1016/j.virusres.2003.12.024

[29] Kablan, L. (2012) Effet Protecteur du Silicium sur la Tolérance du Bananier aux deux Maladies Fongiques. UCL, Belgium, 177.

[30] Bakelana, B. (2005) Participation of Farmers in the Evaluation and Dissemination of Improved Banana Cultivars in Bas Congo Province, DRC: Results of the First Three Years of Activity. Musafrica, 2, 11-13.

[31] Tollens, E. (2004) Les Défis: Sécurité Alimentaire et Culture de Rente Pour l’Exportation: Principale Orientations et Avantage Comparatives, de l’Agriculture en RDC, Kinshasa, République Démocratique du Congo, 34.

[32] Swennen, R. and Vuylsteke, D. (2001) Bananier. In: Ramaekers, H.R, Ed., Agriculture en Afrique Tropicale, DGCI Bruxelles, 611-636.

[33] Selvarajan, R., Sheeba, M.M. and Balasubramanian, V. (2011) Simultaneous Detection of Episomal Banana Streak Mysor Virus and Banana bunchy top virus Using Multiplex RT-RCP. Current Sciences, 100. 


\section{Annexes}

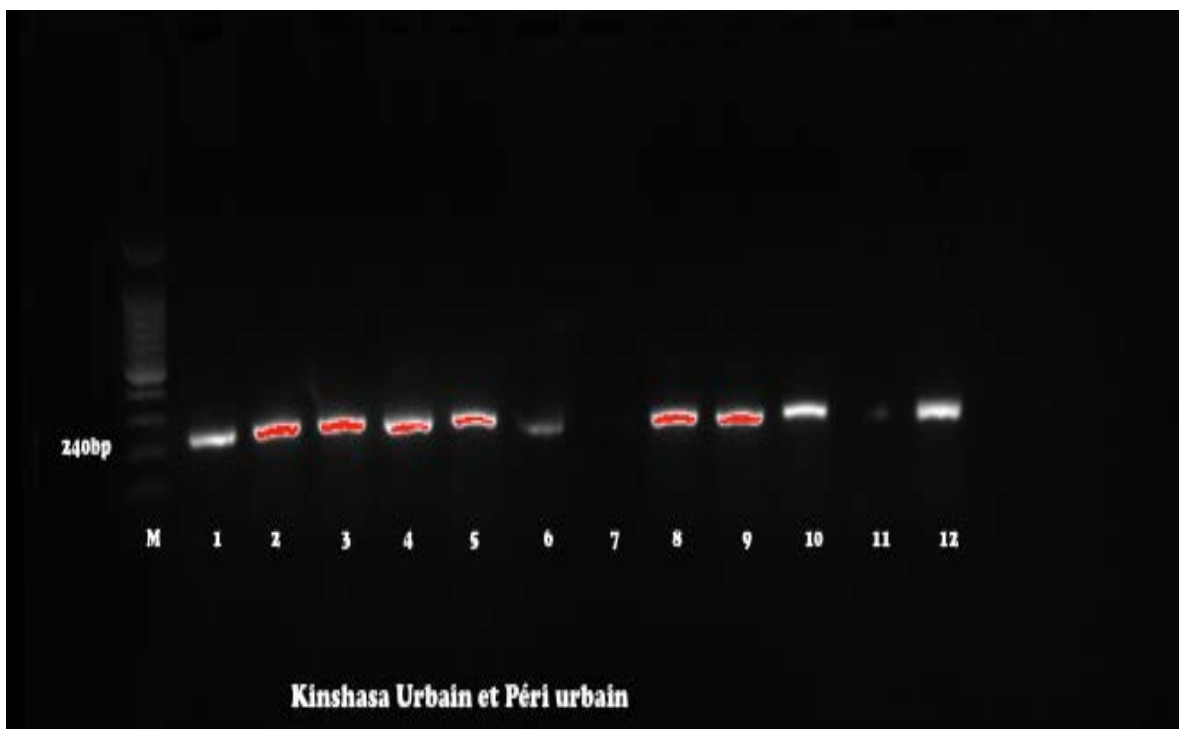

(a)

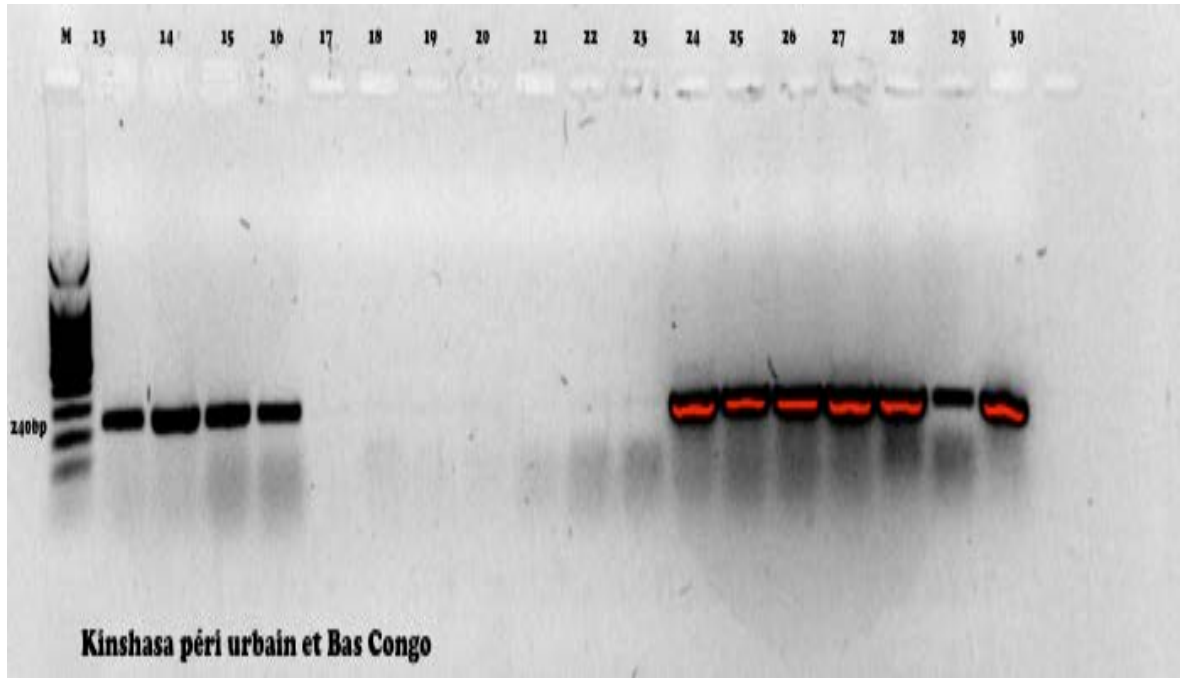

(a \& b)
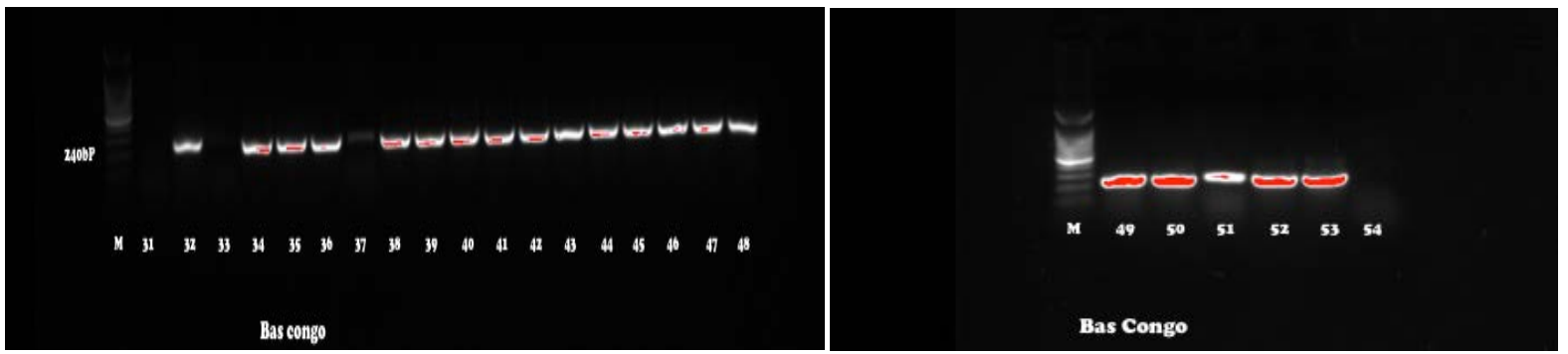

(b)

Figure 1. Molecular detection of Banana bunchy top virus on 54 samples from Bas Congo and urban and péri urban Kinshasa province. Thesites surveyed were: (a) In Bas Congo: Kasavubu-lukula, kinzita-lukula, patuzemba-lukula, kokolo-lukula, 4janvier-lukula ,mawusa-lukula, inera luki, Luila, M’vuazi 1, Kisantu, Madimba, Kinzokimosi, Mbanzangungu, Mwenge- lukula, ELPV lukula. (b) In Kinshasa urban and peri urban: Selembao, KindeleI Montnga fula, Cité verte, N’Djili secomaf, djili brasserie, Menkao, Bandalungwa, Kalamu, Kingabwa, Malueka et Kinsuka pompage, Kasangulu, Maluku. 


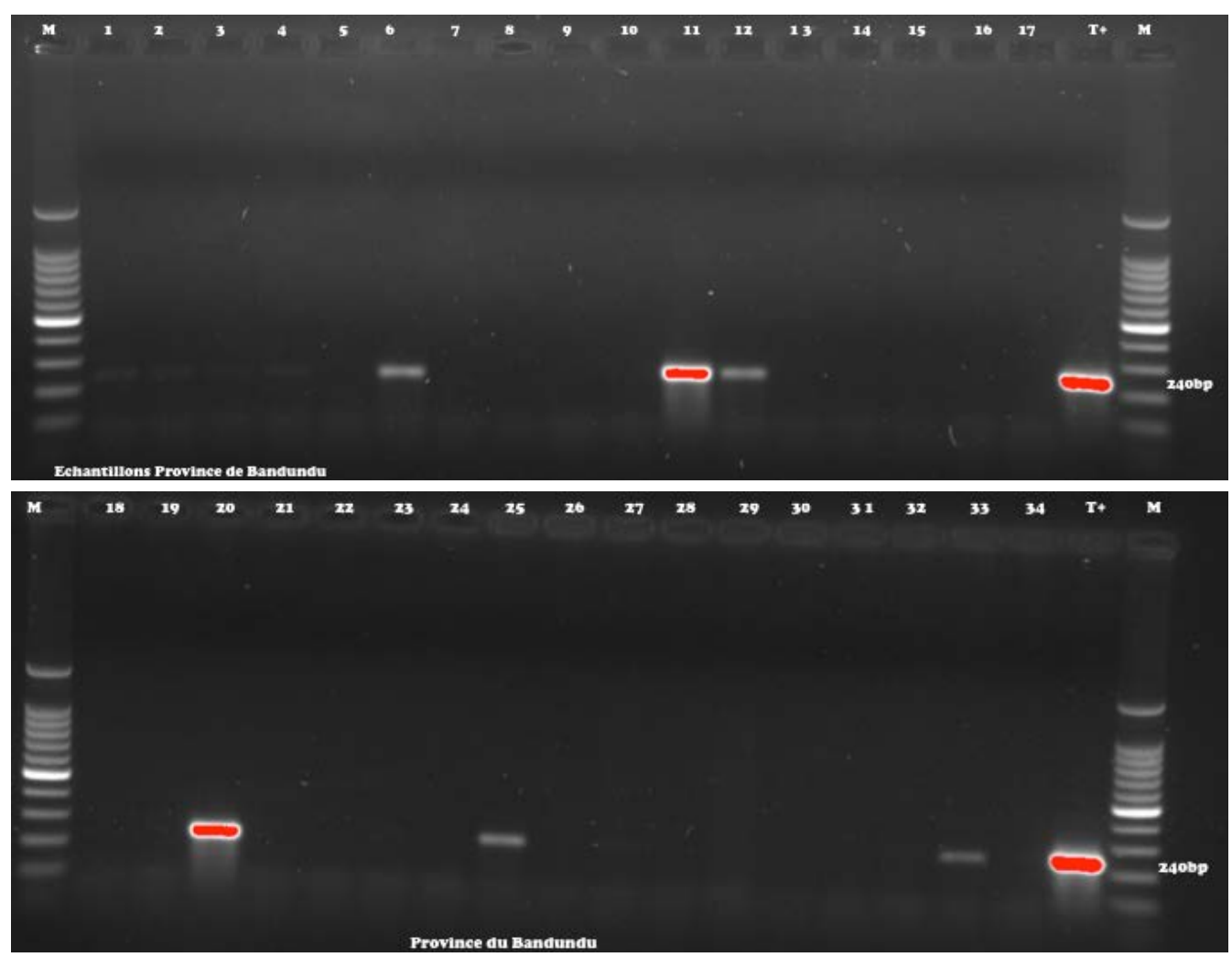

(a)

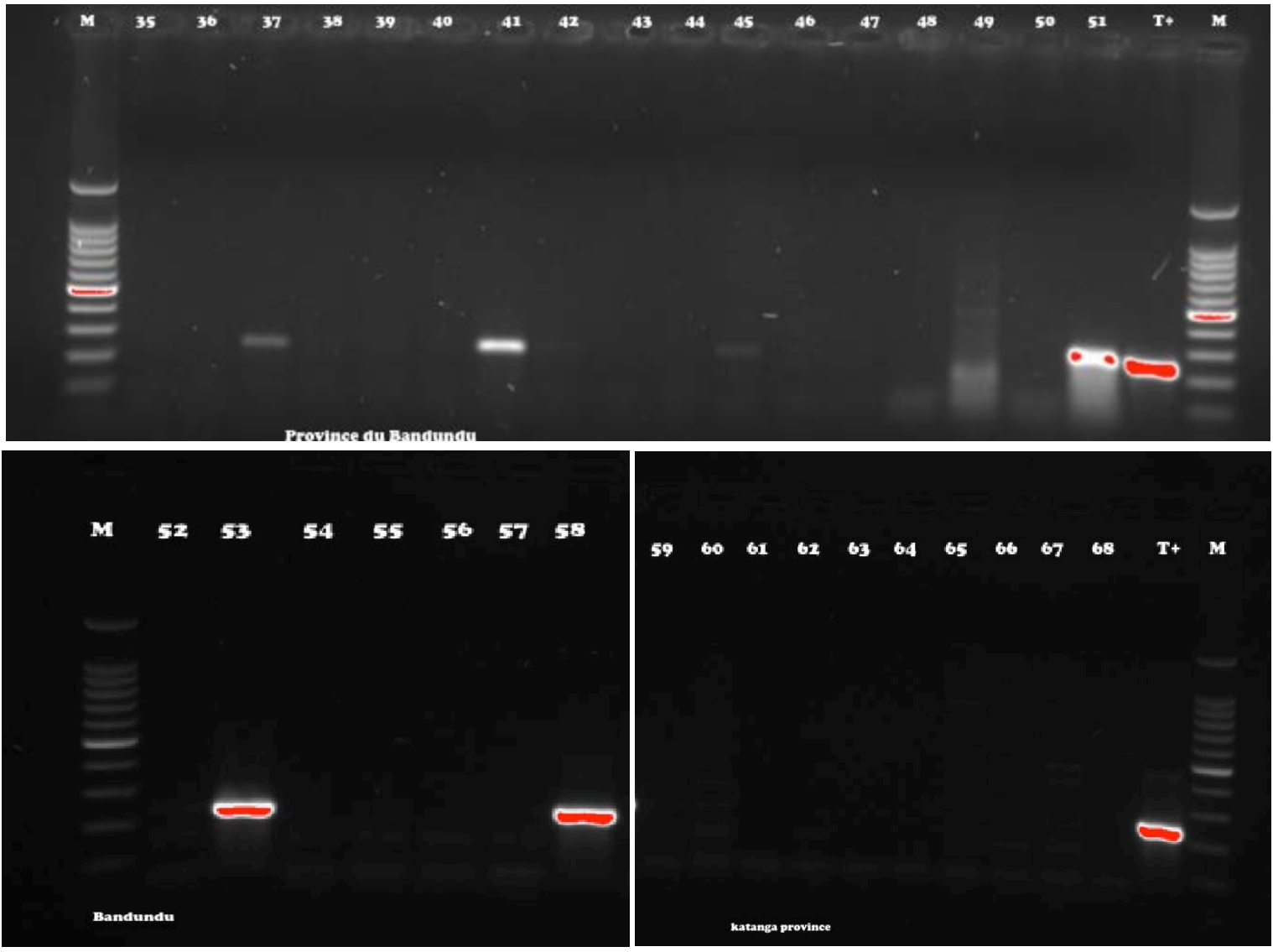



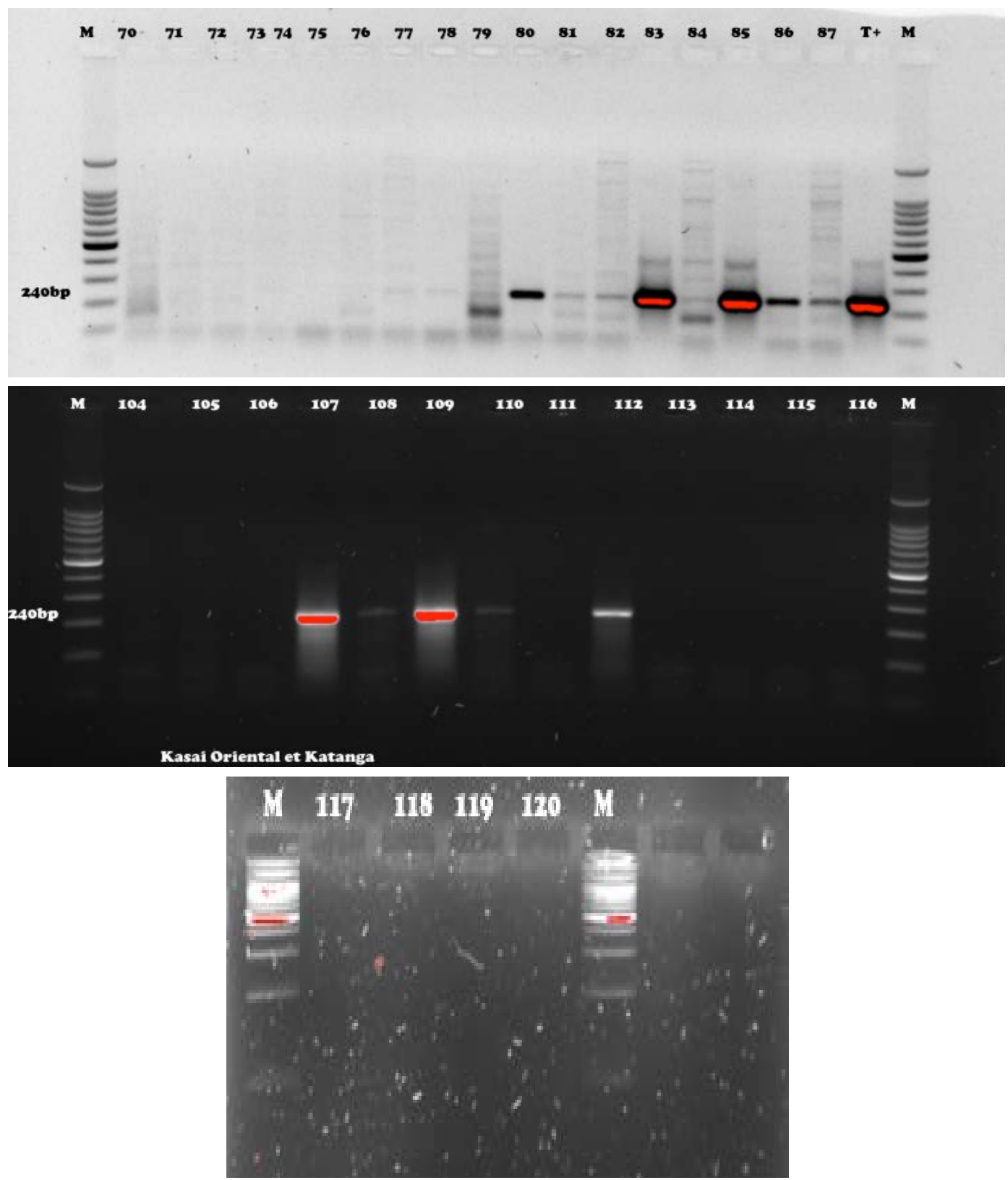

(b)

Figure 2. Molecular detection of Banana bunchy top virus on 120 samples from Bandundu, Katanga and Kasaï Oriental province. (a) In Bandundu province, sites surveyed were: Nkara ewa, kiandu, Kasanza pondo, bulungu, masimanimba, Bumba bar, Longo kumakuma, idiofa, Nkara, Kiyongo, Itsweme, Masamuna, Kimbinga, Kingandu, Kwango, ndalangulu, Mongata, Kasau nzadi, Kingandji, Kiyaka I, Kakobola, KiyakaII, yassa secteur. (b): Kasaï oriental: sites surveyed were: Mpemba Nzeu koloho,miabi, mpiana kamuanya, manda mwembia, route kaseki, Tshilombo, Katamba/ route kanyana, Lusanga/route Kananga, mbujimayi centre, Kakumba/ route kayeka, Manda muswi, mulamba/ dikenda dikunza, mulamba dibota diamputu,, mulamba lufuka, manda mukendi and in Katanga: Kipushi, Kiswishi, ferme kasapa, champs expII, chemchem, Champs expérimenatl I. 